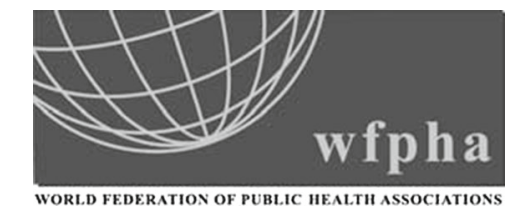

The Federation's Pages

WFPHA: World Federation of Public Health Associations www.wfpha.org

Bettina Borisch and Marta Lomazzi, Federation's Pages Editors

Journal of Public Health Policy (2017) 38, 296-302.

doi:I0.I057/S4I27I-OI7-0065-0; published online, I 7 February 2017

\title{
World Federation of Public Health Associations: 50 years of international leadership for a healthy global society
}

\section{Summary}

The World Federation of Public Health Associations (WFPHA) is an international non-governmental organization (NGO) with official relations to the World Health Organization (WHO) and other United Nations' (UN) agencies. It represents the global community of national and regional public health associations (PHAs) and the worldwide body of public health professionals who work to improve, protect, and promote the public's health. Its mission is to bring a multi-disciplinary, population health-based approach to solving public health problems. The WFPHA celebrates its 5 oth anniversary in 2017. During this first half-century, the WFPHA has played an important role in helping strengthen the capacity of national public health associations to effect positive health changes within their respective jurisdictions, to contribute to advancing public health approaches to the world's pressing issues, and to bring a strong, evidence-based public health voice to global health policy discussions. 


\section{Formulation of the WFPHA}

The concept of an international partnership among national PHAs first emerged in the early I960s. The American Public Health Association (APHA) had canvassed all national PHAs existing at that time, asking their opinion about such a body. Respondents expressed considerable enthusiasm for the idea. ${ }^{\mathrm{I}}$

According to the unpublished minutes of a meeting that took place on May 7, I966, eight individuals (representatives from the national PHAs of India, the USA, and the UK; national government health agency representatives from Philippines, Japan, New Zealand, and the USA; and a representative from WHO) met at the WHO headquarters office in Geneva, Switzerland, to discuss the concept. They agreed to hold an international meeting in October I966, at the time of the APHA's annual meeting in San Francisco, to which all known PHAs would be invited.

An Interim Planning Committee composed of representatives from 6 PHAs (India, Japan, Pakistan, the Philippines, the USA, and the UK) met later that same month in Geneva. According to the unpublished minutes of this meeting, they concurred on the name "World Federation of Public Health Associations."

The San Francisco meeting was pivotal. According to the meeting's unpublished minutes, representatives from II national PHAs attended (Argentina, Chile, India, Israel, Japan, the Netherlands, Nigeria, the Philippines, the USA, the UK, and Venezuela). The meeting produced two key outputs: a draft Constitution and a decision to hold the WFPHA's inaugural meeting in Geneva in May 1967, in conjunction with the 2oth World Health Assembly. The group defined four objectives for the proposed federation, including to encourage and assist the formation of national PHAs and to facilitate the exchange of information and ideas among PHAs to advance the objectives of public health.

\section{The WFPHA is launched}

The WFPHA formally came into being on 20 May I967 through a series of three meetings held at the WHO headquarters building in Geneva. Representatives from I 8 national PHAs attended (Brazil, Ceylon (Sri Lanka), Colombia, France, Hungary, India, Iran, Israel, Italy, Japan, New Zealand, Nigeria, Pakistan, Singapore, Sudan, the UK, the USA, Venezuela, and the Federal Republic of Germany (West Germany)). (Those indicated in italics became WFPHA's founding members - Sudan would be added subsequently). Several countries that were unable to attend, among them, Canada, Mexico, and Australia, expressed interest in the WFPHA. The delegates adopted the draft Constitution, elected the WFPHA's first Officers, 
and formed an Executive Board. ${ }^{2}$ They elected Dr. K.N. Rao of the Indian Public Health Association to be the WFPHA's first President and appointed Dr. A. Hutchison of the Royal Society of Health (UK) as Vice-President and Dr. E. L. Stebbins (APHA) as the WFPHA's first Executive Secretary.

The newly minted Executive Board (EB) then held its inaugural meeting. The meeting set terms for EB members and established three committees. It also resolved to set up a WHO liaison office in Geneva and confirmed the I 5 PHAs noted in the previous paragraph as the WFPHA's Founding Members.

Finally, on the same day, the WFPHA's General Assembly held its first meeting. That group formally approved the WFPHA's Constitution and Executive Board/Officers. ${ }^{3}$ The WFPHA formally launched with the meeting's closure.

\section{The WFPHA's Formative Years}

During the WFPHA's initial General Assembly meeting, Dr. J. Karefa-Smart, WHO Assistant Director General, noted that none of the 7 I NGOs in official relations with WHO at that time was concerned with public health. Nor did any of them advance specifically the cause of public health. ${ }^{4}$ The creation of the WFPHA dramatically changed that situation. In January I97 I, the WHO Executive Board approved the WFPHA's status as an NGO in official relations with the WHO. The following year, the UN Economic and Social Council (ECSOC) approved a similar status for the WFPHA. With this designation, WFPHA gained a position to launch cooperative activities with both organizations, as well as with UNICEF.

The WFPHA opened a WHO liaison office in Geneva, staffed by a parttime volunteer. From the outset, the APHA provided the Secretariat office and staff support in Washington, DC. This gave the WFPHA organizational stability.

During its first decade, the WFPHA became recognized as a significant player in the international health arena. Policy-oriented Technical Discussions were organized to coincide with the WFPHA's Annual General Assembly, which took place each May in Geneva coincidental to the World Health Assembly. The first Technical Discussion was held in May 1970. Over subsequent years, the Technical Discussions focused on the role of national PHAs in the planning and implementation of health programs, family planning, environment, and, food and nutrition policies for health development.

In I970, the Milbank Memorial Fund provided a grant to the APHA to work with the WFPHA to determine the potential of NGOs and national PHAs to become more effective advocates and help their respective governments improve basic health services to all of their population. This would form the 
base for future WFPHA efforts to support the creation and organizational nurturing of PHAs in low- and middle-income countries.

Given their common interests, WHO's Director General, Dr. Halfdan Mahler, invited the WFPHA to take a leadership role in developing a consensus in support of the proposed new global goal of "Health for All by the Year 2000." In 1977, the WHO and UNICEF invited the WFPHA Secretariat to work with the international NGO community to prepare a position paper representing views of NGOs about primary health care (PHC). The results of these consultations formed the basis of discussion at the Federation's 2nd international congress, hosted by the Canadian Public Health Association (CPHA) in Halifax in June I978. (The PHA of the Federal Republic of Germany hosted the Ist WFPHA international conference three years earlier in Bonn-Bad Godesberg.) Non-Governmental Organizations and Primary Health Care, the WFPHA's first policy statement, advocated for a greater involvement of NGOs in the development of national health policies and for a human rights approach to access and appropriate health care for the preservation and promotion of health. ${ }^{6,7}$

In September 1978, the WFPHA's President delivered the position paper in a keynote address at a plenary session during the landmark WHO/ UNICEF International Conference on Primary Health Care in Alma-Ata (former USSR). The high profile role of the WFPHA at this conference and its input to the crafting of the Alma-Ata Declaration, the positive support the conference delegates gave the NGO document, and the subsequent PHC leadership award presented to the WFPHA by the WHO Director General set the stage for the WFPHA to become one of the NGO international health leaders.

\section{WFPHA's Growth Years}

The next two decades saw a significant expansion of the Federation's membership base. At the time of the Federation's establishment in 1967, the APHA had identified 25 national PHAs, the majority of these located in Europe and the Americas region. In I98I, the Federation's membership stood at 3 I organizations, of which 28 were national PHAs.

By the beginning of the 2ist Century, the number of national PHA members in the WFPHA had risen to 63 (it now stands at over 90). The majority of the new members were located in Africa and Central/Eastern Europe. It was during this period that the CPHA, with funding support from the Government of Canada, provided financial and technical support to emerging PHAs in low- and middle-income countries. Over its 25 years of existence (1985-2010), the Strengthening of Public Health Associations 
(SOPHA) Program supported the creation and organizational nurturing of 30 national PHAs and 2 regional PHAs, all of which became active within the WFPHA. ${ }^{8}$

With a strengthened institutional base and a solid international reputation as a science-based organization, the Federation was well placed to have its voice heard on a number of major public health issues. Over the period I98 I to 2000 , the WFPHA released position papers on a variety of public health issues, including globalization, tobacco control, international trade, peace and conflict, access to primary health services, the environment, and climate change. ${ }^{9}$

In 1997, the WFPHA held its 8th International Congress in Arusha, Tanzania. This was a watershed event for a number of reasons. First, it was the largest public health meeting ever held in Africa and brought together English-, French-, and Portuguese-speaking public health professionals. Second, the Congress was the venue for a panel of all the candidates for the position of WHO Director General to present their positions on the leadership of the $\mathrm{WHO}$ and respond to the many questions put to them by the Congress participants. The Federation's congress was being seen as a critical forum for this level of global health leadership debate.

\section{The New Millennium and Beyond}

The dawn of the new century saw WFPHA become a more active advocate for public health and health equity. The WFPHA hosted, prior to its 9th international congress in Beijing (PRC), a Leadership Forum to develop a strategy for the Federation's work for the coming decade. WFPHA reconfirmed primary health care as a worthy strategy to reduce inequities within countries. It also recommitted to the principles of equity and social justice in the building of national health systems and recognized the need for strategic engagement by the public health community with the social determinants of health. The Leadership Forum also called for increased investments in public health and strengthening of essential public health functions. The Forum's output, Challenges for Public Health at the Dawn of the 2 Ist Century: A Call to Action, was adopted as the Federation's 5-year strategic plan. ${ }^{\mathrm{IO}}$

Four years later, during the Ioth World Congress on Public Health in Brighton (UK), the Federation called for a new public health paradigm. The Brighton Declaration reconfirmed health as a global public good and a key component of global security; it also identified global health governance, health citizenship, and health as responsible business practices and key elements of a global health strategy. ${ }^{\text {I }}$ 
In another WFPHA milestone, in 2010-after 43 years of Secretariat office support provided by the APHA - the WFPHA General Assembly approved the transition of the WFPHA international office from Washington to Geneva. The APHA provided a special grant to facilitate this transition which took place the following year. The WFPHA also encouraged and supported the establishment of the Asia-Pacific Region Liaison Office (2010) in Beijing, the creation of the African Federation of Public Health Associations (2OII) (its secretariat is located in Addis Ababa) and in April 20I 5 , the founding of the Alliance of Public Health Associations in the Americas region (hosted by the Sociedad Cubana de Salud Pública in Havana). The European Public Health Association, a WFPHA regional member since I995, was founded as an independent organization in 1992.

With the approach of the year 2015, the WFPHA called attention to some of the shortcomings of the Millennium Development Goals. It called upon governments, NGOs, and health agencies to pay special attention to the issue of health equity. It also called for greater attention to 'the place of public health' within the Sustainable Development Goals.

Dr. Margaret Chan, WHO Director General, invited the WFPHA in $20 \mathrm{I} 2$ to help define public health within today's complex global settings. In 2016 , the WFPHA released its Global Charter for the Public's Health. ${ }^{\text {I2 }}$ Building upon the Alma-Ata Declaration ${ }^{\mathrm{I}}$, the Ottawa Charter for Health Promotion ${ }^{\mathrm{I} 4}$ and the Federation's previous Declarations, the new Charter maps out a framework for essential public health functions within the context of the Sustainable Development Goals and in support of Universal Health Coverage.

\section{The next 50 years...}

Over its 50-year history, the WFPHA has largely achieved its four original objectives. The Federation is now an ardent advocate for the public's health and facilitates links among the world's PHA community for 'best practice' in public health policy and practice. As it charts its course for the next 50 years, the WFPHA will continue to be the nexus of the world's public health community and a strong voice for global public health.

James Chauvin ${ }^{\mathrm{a}}$, Margaret Hilson ${ }^{\mathrm{b}}$ and Russell E. Morgan Jr. ${ }^{\mathrm{c}}$

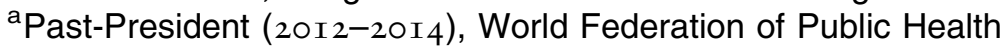
Associations, Gatineau, QC, Canada.

E-mail: jamesbchauvin@gmail.com

${ }^{\text {b}}$ Past-President (I999-200I \& 2003-2004), World Federation of Public Health Associations, Vancouver, BC, Canada.

${ }^{\mathrm{c}}$ Former WFPHA Executive Secretary (1972-1979), Chevy Chase, MD, USA. 


\section{References}

I. American Public Health Association. (1966) Report of the Chairman of the Executive Board of the American Public Health Association to the Governing Council at the 94th Annual Meeting in San Francisco (CA). Washington (DC): APHA.

2. World Federation of Public Health Associations. (1967) Minutes of the Inaugural Meeting held in the WHO building, Geneva, on 2oth May, I967, at I0.30 hours. Geneva: WFPHA.

3. World Federation of Public Health Associations. (1967) Minutes of the meeting of the General Assembly, held in the WHO building on Saturday, 2oth May, I967, at I5.30 hours. Geneva: WFPHA.

4. Karefa-Smart J. (1967) Inaugural Meeting of the World Federation of Public Health Associations, Geneva, 20 May 1967. Geneva: WHO. 29 May I967 Document No.: E $3 / 348 / 3$.

5. Mahler, H. (198I) The meaning of "Health for All by the Year 2000 ". World Health Forum, 2(I), 5-22.

6. World Federation of Public Health Associations. (1978) Non-Governmental Organizations and Primary Health Care: A Position Paper prepared for the International Conference on Primary Health Care. Washington (DC): WFPHA.

7. World Federation of Public Health Associations. (1978) Non-Governmental Organizations and Primary Health Care. Halifax (NS): CPHA, http://www.wfpha.org/tl_files/doc/resolutions/ positionpapers/global/NGO\&PrimaryHealthCare.pdf.

8. Canadian Public Health Association. (20II) The Public Health Association Movement25 years of building a civil society voice for public health. Ottawa: CPHA, http://www.cpha. ca/uploads/progs/_/sopha/sopha_publication_s.pdf.

9. World Federation of Public Health Associations. (2016) Resolutions. Geneva: WFPHA, http://www.wfpha.org/policy-and-advocacy/resolutions.html.

Io. World Federation of Public Health Associations. (2000) Challenges for Public Health at the Dawn of the 2 s st Century: A Call to Action. Beijing: WFPHA.

I I. World Federation of Public Health Associations. (2004) The Brighton declaration - we are all responsible for the developing world. Public Health News, 22, I-2.

I2. Lomazzi, M. (20I6) A global charter for the public's health - the public health system: role, functions, competencies and education requirements. European Journal of Public Health, 26(2), 2IO-2I 2.

I3. World Health Organization. (I978) Declaration of Alma-Ata. Alma-Ata, USSR: World Health Organization, http://www.who.int/publications/almaata_declaration_en.pdf?ua=I.

I4. World Health Organization. (I986) The Ottawa Charter for Health Promotion. Geneva: WHO, http://www.who.int/healthpromotion/conferences/previous/ottawa/en/. 